\title{
Development of Scientific Learning Devices to Increase Critical Thinking Ability and Skills of Science Processes of Students in Middle School Using Problem Solving Models
}

\author{
Juli Eka Nugraheni*, Suryajaya, Abdullah \\ Masters Program of Natural Sciences Teaching, Lambung Mangkurat University, Banjarmasin, Indonesia
}

DOI: $10.36348 /$ jaep.2020.v04i03.004

| Received: 07.03.2020 | Accepted: 14.03.2020 | Published: 21.03 .2020

*Corresponding author: Juli Eka Nugraheni

\section{Abstract}

This study aims: (1) evaluating the validity of the learning tools developed seen from the validation test, (2) evaluating the practicality of the learning tools developed seen from the implementation of the Learning Implementation Plan (RPP) during the learning process, (3) evaluating the effectiveness of the learning tools developed seen from tests of learning outcomes, critical thinking skills, science process skills, attitudes and skills of students. This study uses a Tessmer development research model consisting of 5 steps, namely: (1) self-evaluation; (2) expert opinions (expert review); (3) individual trials (one to one); (4) small group trials; and (5) field test. The trial design is guided by the formative evaluation flow design, which is to find out the validity, practicality, and effectiveness of the developed device. Trial subjects at the individual trial stage consisted of 3 people, at the small group trial stage consisted of 5 people, a field test with 30 students with different levels of knowledge and all subjects were $7^{\text {th }}$ Grade students. The results of the study concluded that: (1) Valid learning tools based on expert opinion include, syllabus, material analysis, teaching material, worksheets, student critical thinking skills assessment sheets, students' science process skills assessment sheets, teacher activity assessment sheets, and activity assessment sheets learners; (2) Learning tools are considered practical based on the activities of teachers and students who are very good from the implementation of lesson plans, self-assessment and students' responses are categorized as good; (3) Learning tools are considered effective based on learning outcomes that have exceeded the Minimum Mastery Criteria that have been set, the ability to think critically and the science process skills are increasing, and the attitudes and skills of students are categorized well.

Keywords: Critical thinking, science process skills, problem solving.

Copyright @ 2020: This is an open-access article distributed under the terms of the Creative Commons Attribution license which permits unrestricted use, distribution, and reproduction in any medium for non-commercial use (NonCommercial, or CC-BY-NC) provided the original author and sources are credited.

\section{INTRODUCTION}

Science learning has so far been judged to be far from what is expected, which is carried out by teachers with more emphasis on mastering a number of facts and concepts [1,2]. The use of teaching methods that are not varied is often carried out in every learning activity, so learning activities are often dominated by teachers which results in students becoming passive and quickly feeling bored in learning. The interest of students to learn science is low because it is considered science lessons are boring lessons.

Ningsih [3] explained that in reality science learning at this time only studied science as a product by memorizing concepts, theories and laws. The reason is the limited time, facilities, learning environment, and the number of students per class that is too much. Some of these reasons can indirectly result in students not accustomed to thinking critically and becoming passive in learning.

The scientific ability of Indonesian students in the PISA studies of 2000, 2003, 2006, 2009, and 2012 has an average score of 393, 395, 395, 383, and 382, respectively [4]. This result is below the average international score which reaches a score of 500. This shows that the scientific ability of Indonesian students is still very low and only reaches the ability to recognize a number of basic facts, and has not been able to communicate and link these abilities in abstracts.

The results of the assessment of the field of science achievements of Indonesian students in 2011 were 406 [5] so that Indonesia was ranked 40 out of 63 countries [6]. Based on these data shows that overall students in Indonesia have not been able to identify, explain, apply knowledge and science in various 
complex life situations, and scientific attitudes are still low. The low results achieved are not separate from students' interest in learning and thinking ability. The ability of students to solve problems that demand the ability to think and reason is still low. Students are not trained to think critically and only tend to memorize formulas rather than understanding concepts. Studentcentered learning should give students room to learn according to their interests, personal abilities and learning styles.

Critical thinking is a skill in sorting which is valuable from many ideas or making consideration of a decision [7]. According to Falsaime [8], there are five indicators in critical thinking, namely identifying problems, defining problems clearly, exploring problems and possible solutions, evaluating their application, and integrating understanding with existing knowledge.

So that teaching and learning activities are in accordance with the expected goals, then the right strategies and teaching methods are needed. Gafur [9] explained that learning strategies are important in planning, implementing and evaluating learning. Thus, the role of teaching strategies is more important if the teacher teaches students who are different in terms of abilities, achievements, tendencies and interests.

Teaching based on the problem solving approach is to use teaching strategies that develop or enhance students' abilities in solving problems and thinking skills. This will make students to display higher-order thinking skills such as asking questions, finding problems, making hypotheses, planning investigations, expecting desired results, conducting experiments, collecting and evaluating data, concluding, expressing ideas, evaluating other ideas and looking for alternatives interpretation [10].

Huda [11] explained that in learning with the Problem Solving model occurs when students are trying to solve problems. Tawil and Liliasari [7] state that skills in solving problems by proposing alternative solutions to problems and testing them for feasibility. According to Greiff et al. [12], the ability to solve problems consists of understanding problems, finding solutions, and communicating the results of problem solving.

Problem solving model will make students think critically in solving a problem. Seyhan [13], in his research revealed that by using the problem solving model, students will always think critically and suggest various ideas and solutions throughout the problem solving process. Problem solving also emphasizes the science process skills so as to improve student performance. The results of other studies show that using the problem solving model turns out to make students more able to develop thinking skills [10].
According to Mukhopadhyay [14], problem solving models will encourage students to recognize problems more effectively and have the ability to solve problems and thinking skills.

Science learning activities require students to develop science process skills so that learning activities are more meaningful, because these skills will facilitate learning of science, activate students, develop a sense of responsibility in learning, and teach them research methods. Deslimar et al. [15] Revealed that science process skills consist of several points namely observation, prediction, inferring, classifying, communicating and measuring. Hidayat et al. [16] Explained that integrated science process skills include formulating problems, identifying variables, presenting data, analyzing data, formulating hypotheses, and conducting investigations/experiments. Thus, students are expected to gain their own experience and knowledge, conduct scientific investigations, practice their intellectual abilities, and stimulate curiosity and can motivate to acquire new knowledge.

Seyhan [13], the main purpose of teaching science is that students have critical thinking skills and problem solving, become lifelong learners, and increase their curiosity about the environment. Therefore, it is very important for students to acquire science process skills that enable them to produce scientific knowledge and learn natural knowledge through experience. Improving science process skills will enable students to solve problems, think critically, make decisions, find answers, and fulfill their curiosity.

The subject matter of environmental pollution was raised in the research development of this learning device because the problem of environmental pollution is not a foreign problem for students, because environmental pollution has indeed occurred in their immediate surroundings, including: water pollution, air pollution and soil pollution. Environmental pollution has become an important issue as community awareness of the surrounding environment increases. To overcome the problem of environmental pollution students are required to think critically and be able to apply the science process skills in determining their attitudes to make appropriate efforts to overcome environmental pollution, as well as the existence of ideas or ideas to solve environmental pollution problems.

\section{RESEARCH METHODS}

This study uses the Tessmer development research model. According to Akker [17], the Tessmer development model consists of five steps. The five steps are as follows: 1) self evaluation; 2) expert review; 3) one to one test; 4) small group test; and 5) field test. Validity is obtained from expert opinion for validity of syllabus, lesson plans, teaching materials, and assessment instruments for content validity, constructs, and language. Validation was carried out by 3 experts. 
Practicality is obtained through individual tests, small group tests, and field tests by analyzing teacher activity data in managing learning. Effectiveness is obtained through small group trials and field tests by analyzing student activity data, student responses, and learning outcomes. The subjects of the trial were students of class VII at SMPN 19 Banjarmasin who had various levels of knowledge with a total of 38 students throughout the study. Data collection techniques are done through observation, documentation, and tests.

\section{RESEARCH RESULTS AND DISCUSSION Research Results \\ Learning Device Validation Results}

The development of learning tools is validated by experts in accordance with their fields of expertise in order to obtain a valid learning device. The prototype of the device was declared valid by the three equipment inspectors with a few minor revisions. Suggestions for revision of the results of expert studies in the form of writing adjusted to the SPOK rules, the suitability of the material with the conditions of the surrounding environment, learning plans written in straightforward language, teaching materials made interesting, and revised worksheets in order to stimulate critical thinking skills and students' science process skills. While the student response test to the learning device shows a good device to use and can attract students' interest to learn it.

\section{Practical Results of Learning Devices}

There are 4 types of results taken for the assessment of the practicality of learning tools, namely teacher activity, student activity, self-assessment, and student response. The results of practicality tests of teacher activities can be seen in Table 1 .

Table-1: Teacher Activity Results

\begin{tabular}{|c|c|c|c|c|c|c|c|c|c|}
\hline \multirow[t]{2}{*}{ No } & \multirow[t]{2}{*}{ Type of activity } & \multicolumn{4}{|c|}{ Average Score for Each Meeting } & \multirow[t]{2}{*}{ Means } & \multirow[t]{2}{*}{ Max Score } & \multirow[t]{2}{*}{$\%$} & \multirow[t]{2}{*}{ Category } \\
\hline & & 1 & 2 & 3 & 4 & & & & \\
\hline 1. & pre-teaching & 3 & 3 & 3 & 3 & 3,00 & 4 & 75,0 & Good \\
\hline 2. & whilst-teaching & 2,3 & 2,7 & 3,2 & 3,5 & 2,90 & 4 & 72,5 & Good \\
\hline 3. & post-teaching & 3 & 3 & 3 & 3 & 3,00 & 4 & 75,0 & Good \\
\hline
\end{tabular}

As for the results of the practicality test activities of students can be seen in Table 2

Table-2: Student Activity Results

\begin{tabular}{|c|c|c|c|c|c|c|c|c|c|}
\hline \multirow[t]{2}{*}{ No } & \multirow[t]{2}{*}{$\begin{array}{l}\text { Type of } \\
\text { activity }\end{array}$} & \multicolumn{4}{|c|}{$\begin{array}{c}\text { Average Score for Each } \\
\text { Meeting }\end{array}$} & \multirow[t]{2}{*}{ Means } & \multirow[t]{2}{*}{$\begin{array}{c}\text { Max } \\
\text { Score }\end{array}$} & \multirow[t]{2}{*}{$\%$} & \multirow[t]{2}{*}{ Category } \\
\hline & & 1 & 2 & 3 & 4 & & & & \\
\hline 1. & pre-teaching & 2 & 3 & 3 & 4 & 3,00 & 4 & 75 & Good \\
\hline 2. & whilst-teaching & 2 & 2,3 & 2,5 & 2,8 & 2,40 & 4 & 60 & Quite Good \\
\hline 3. & post-teaching & 2 & 3 & 3 & 4 & 3,00 & 4 & 75 & Good \\
\hline
\end{tabular}

In addition to assessing the results of the activities of teachers and students, practicality also evaluates self-assessment in the form of a questionnaire consisting of 10 statements of positive and negative value. The results of self-assessment can be seen in Table 3.

Table-3: Student Self-Assessment

\begin{tabular}{|l|l|c|c|}
\hline No & \multicolumn{1}{|c|}{ The observed aspect } & Score & \% \\
\hline 1 & I always work with groupmates when working on group assignments & $(+)$ & 100 \\
\hline 2 & I recorded data carefully and in accordance with facts & $(+)$ & 80 \\
\hline 3 & I do my tasks according to a predetermined schedule & $(+)$ & 80 \\
\hline 4 & $\begin{array}{l}\text { I completed the assignment based on various literature related to the } \\
\text { subject matter being studied }\end{array}$ & $(+)$ & 100 \\
\hline 5 & I really liked the science lesson & $(+)$ & 100 \\
\hline 6 & I like the science practicum activities & $(+)$ & 100 \\
\hline 7 & I always do homework (homework) at school & $(-)$ & 40 \\
\hline 8 & I'm lazy to do my science homework & $(-)$ & 0 \\
\hline 9 & I have the ability to think critically & $(+)$ & 80 \\
\hline 10 & I have the science process skills in learning science & $(+)$ & 80 \\
\hline
\end{tabular}

Based on the data in Table 3 there are some positive aspects with a high percentage, this shows that students have been able to participate in learning activities well. But there is also a negative aspect with a nearly high percentage of aspect 7 where there are some students who are still doing homework (homework) at school, this can still be overcome by giving good motivation to students to no longer do homework at 
school. In general, self-assessment is good and categorized as practical so that it can be continued for the next stage, namely the field test (field test) to obtain actual effectiveness.
Student responses developed in the form of a questionnaire that must be filled in after the learning activities are finished. Student responses are used to determine students' interest in learning activities using the Problem Solving learning model. The results of students' responses can be seen in Table 4.

Table-4: Student Responses

\begin{tabular}{|c|c|c|c|c|c|c|c|}
\hline \multirow[t]{2}{*}{ No } & \multirow[t]{2}{*}{ The observed aspect } & \multicolumn{5}{|c|}{ Student Score } & \multirow[t]{2}{*}{$\%$} \\
\hline & & 1 & 2 & 3 & 4 & 5 & \\
\hline 1 & $\begin{array}{l}\text { Learning tools using the Problem Solving model can improve critical thinking } \\
\text { skills so I am very interested in learning about the subject matter of environmental } \\
\text { pollution }\end{array}$ & 5 & 4 & 5 & 3 & 4 & 84 \\
\hline 2 & $\begin{array}{l}\text { The learning tool with the Problem Solving model can improve the science process } \\
\text { skills so I enjoy learning the subject matter of environmental pollution }\end{array}$ & 4 & 4 & 4 & 5 & 3 & 80 \\
\hline 3 & $\begin{array}{l}\text { The learning tool with the Problem Solving model motivates me to improve my } \\
\text { critical thinking skills in learning the subject matter of environmental pollution }\end{array}$ & 5 & 4 & 5 & 4 & 4 & 88 \\
\hline 4 & $\begin{array}{l}\text { The learning tool with the Problem Solving model makes me challenged to think } \\
\text { critically in solving problems on the subject matter of environmental pollution }\end{array}$ & 4 & 3 & 3 & 4 & 3 & 68 \\
\hline 5 & $\begin{array}{l}\text { Learning tools using the Problem Solving model can improve my science process } \\
\text { skills to solve problems on the subject matter of environmental pollution }\end{array}$ & 4 & 4 & 4 & 4 & 4 & 80 \\
\hline 6 & $\begin{array}{l}\text { The learning tool with the Problem Solving model that involves practicum } \\
\text { activities and discussions, provides an opportunity for me to think critically in } \\
\text { solving problems related to the subject matter of environmental pollution }\end{array}$ & 5 & 5 & 4 & 4 & 3 & 84 \\
\hline 7 & $\begin{array}{l}\text { A learning tool with a Problem Solving model that involves practicum activities } \\
\text { and discussions, gives me the opportunity to improve my science process skills in } \\
\text { solving problems related to the subject matter of environmental pollution }\end{array}$ & 5 & 5 & 3 & 3 & 4 & 80 \\
\hline 8 & $\begin{array}{l}\text { Learning activities carried out in small groups on the Problem Solving model make } \\
\text { me able to work with friends in groups and can improve my ability to think } \\
\text { critically to solve problems related to the subject matter of environmental pollution }\end{array}$ & 4 & 4 & 4 & 4 & 4 & 80 \\
\hline 9 & $\begin{array}{l}\text { Learning activities carried out in small groups on the Problem Solving model } \\
\text { allows me to work with friends in groups and can improve science process skills in } \\
\text { solving problems related to the subject matter of environmental pollution }\end{array}$ & 4 & 5 & 5 & 4 & 4 & 88 \\
\hline 10 & $\begin{array}{l}\text { The learning tool with the Problem Solving model can make me pour ideas / ideas } \\
\text { without any restrictions so as to further enhance the critical thinking skills that I } \\
\text { had before }\end{array}$ & 4 & 4 & 4 & 4 & 4 & 80 \\
\hline
\end{tabular}

\section{The Effectiveness of Learning Tools}

Field test results state the effectiveness of learning tools that are stated as actual effectiveness, determined based on students' achievement during the learning process, which includes learning outcomes, critical thinking skills, and science process skills.

\section{Learning Outcomes}

Student learning outcomes are obtained from the post-test scores given by the teacher to students after completion of learning at each meeting. The post test questions given are adjusted to the learning material being studied at each meeting. Field test results on the effectiveness of student learning outcomes in the form of mastery learning outcomes can be seen in Figure 1.

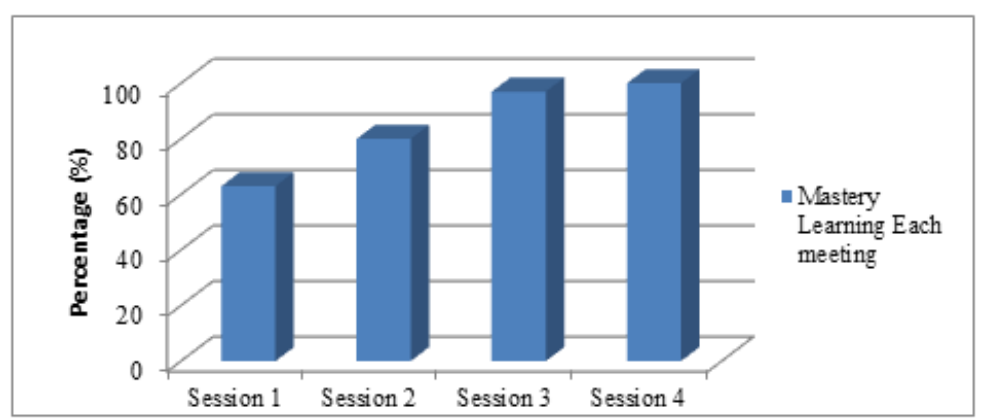

Fig-1: Completeness of Student Learning Outcomes in the Field Test

Based on Figure 1, the percentage of completeness of student learning outcomes at each meeting based on the limits of the minimum completeness criteria (KKM) of schools for science subjects that have been determined is 70 . At meeting 1 , of 30 students there were 19 people who completed and 
11 people incomplete, so the percentage of completeness is $63 \%$. At meeting 2, out of 30 students there were 6 people who did not complete, so the percentage of completeness was $80 \%$. At meeting 3, out of 30 students there was 1 person who did not complete, so the percentage of completeness was $97 \%$. At meeting 4 , all students were completed and the percentage of completeness was $100 \%$. Overall the value of students is good, can complete the learning outcomes thoroughly, so it can be said to be effective and can be applied during the learning process.

\section{Critical Thinking Ability}

Assessment of students' critical thinking skills is seen from the pre-test and post-test scores. Students' critical thinking skills based on pre-test and post-test scores can be seen in Figure 2.

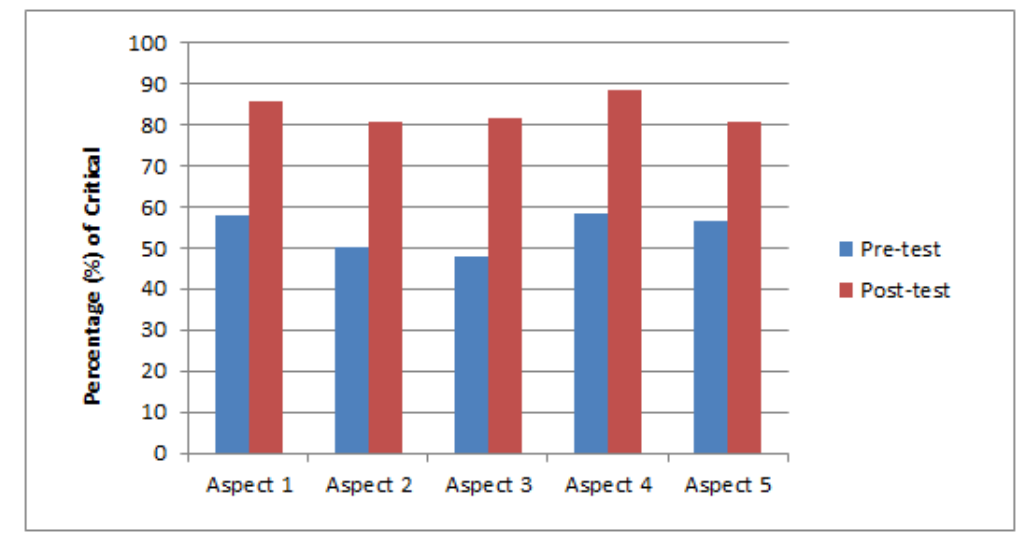

Fig-2: Pre-test and Post-test Students' Critical Thinking Ability in the Field Test

\section{Information}

Aspect 1: Provide a simple explanation

(Indicator: focus questions, analyze arguments / questions, ask and answer questions)

\section{Aspect 2: Build basic skills}

(Indicator: Considering whether sources are reliable or not, observing and considering observational reports)

Aspect 3: Conclude

(Indicator: Induce and consider the results of deduction, induce and consider the results of induction, make and determine the outcome of consideration)

Aspect 4: Provide further explanation

(Indicator: Defining terms and considering a definition, identifying assumptions)

\section{Aspect 5: Arrange strategies and tactics \\ (Indicator: Determine an action, interact with others)}

Overall critical thinking skills of students increased significantly from $54 \%$ to $83 \%$, this shows that students have experienced an increase in critical thinking skills so that they can be categorized effectively. The acquisition of the average value of the $\mathrm{N}-$ Gain in the field test can be seen in table 5 .

Table-5: Value of N-Gain Critical Thinking in Field Test

\begin{tabular}{|c|c|c|c|c|}
\hline Pre-test & Post-test & Gain & N-Gain & Category \\
\hline 54 & 83 & 29 & 0,6 & Sufficient \\
\hline
\end{tabular}

Based on Table 5, the $\mathrm{N}$-gain in the field test has a moderate category. This means that all students already have a good understanding and mastery of concepts and critical thinking skills after using the learning tools that have been developed.

\section{Science Process Skills}

Assessment of students' science process skills which consists of formulating problems, formulating hypotheses, collecting data, conducting experiments, analyzing data, drawing conclusions, and communicating views of the pre-test and post-test scores in the form of test items in the form of description items. Pre-test and post-test aims to determine the extent to which students are able to carry out the science process skills before and after the learning process. Science process skills of students based on pre-test and post-test scores can be seen in Figure 3. 


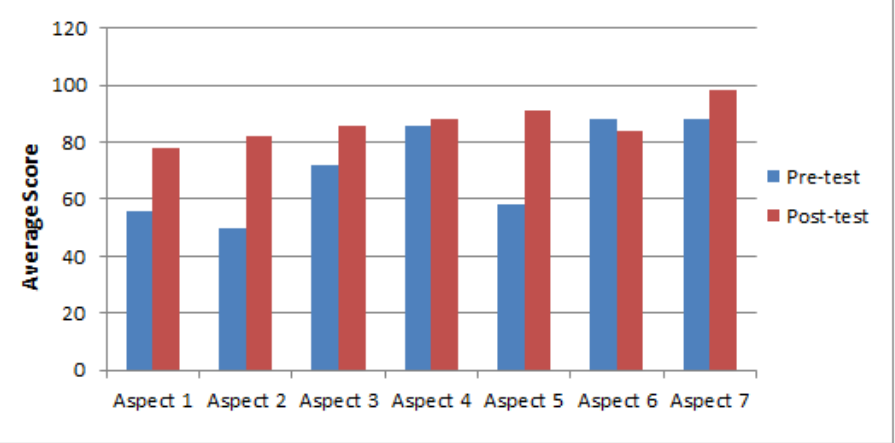

Fig-3: Pre-test and Post-test Students' Science Process Skills in the Field Test

Information:

Aspect 1: Formulate the problem

Aspect 2: Formulate a hypothesis

Aspect 3: Collecting data

Aspect 4: Conduct an experiment

Aspect 5: Analyze data

Aspect 6: Draw conclusions
Aspect 7: Communicate

Overall the average post-test score of students increased by $16 \%$ from the average value of the pre-test so that it can be categorized as effective. The acquisition of the average value of the N-Gain in the field test can be seen in Table 6 .

Table-6: N-Gain Value in Field Test Science Process Skills

\begin{tabular}{|c|c|c|c|c|}
\hline Pre-test & Post-test & Gain & N-Gain & Category \\
\hline 71 & 87 & 16 & 0,6 & Sufficient \\
\hline
\end{tabular}

Based on Table $6 \mathrm{~N}$-gain in the field test (field test) has a medium category, this means that all students already have good science process skills after using the learning tools that have been developed.

\section{DISCUSSION}

\section{Validity of Learning Devices}

The validity of the measured learning instrument is content validity based on the opinions of experts (experts and practitioners). In general, after going through the revision stage of learning tools that have been developed include syllabus, material analysis, lesson plans, teaching materials, worksheets, and assessment sheets are categorized as valid and very valid. Based on the results of the validator / expert / expert / practitioner assessment of the syllabus, out of 10 indicators assessed there were 8 indicators that were declared highly valid and 2 indicators that were declared valid, with minor revisions in the form of suggestions from experts. The syllabus development is adjusted to the 2013 curriculum and uses a problem solving learning model so that it can help students to improve and develop their abilities on the subject matter of environmental pollution. According to Akbar [30], the syllabus should cover all aspects of competence in terms of attitude, knowledge, and skills in order to realize life skills. Practitioner. Analysis of the material developed consists of facts, concepts, procedural, and metacognitive.

Based on the results of the expert's assessment of the lesson plan shows that of the 16 indicators assessed there were 14 indicators declared very valid and 2 indicators declared valid, with minor revisions in the form of advice from experts. The results of the assessment in the category of very valid include the fulfillment of complete components of the RPP namely school identity, subject identity, class / semester, subject matter, time allocation, Core Competencies, Basic Competencies, learning objectives, achievement indicators, learning methods, learning media, learning resources learning activities and assessment of learning outcomes. According to Permendikbud [18], each teacher is obliged to prepare a complete and systematic lesson plan so that learning takes place interactively, inspiratively, fun, efficiently, motivating students to participate actively, creatively, and independently.

Based on the results of expert assessments of teaching materials, out of 16 indicators assessed 10 indicators were declared highly valid and 6 indicators were valid, with minor revisions in the form of advice from experts / practitioners. Teaching material book consists of front cover, table of contents, concept map, apperception, subject matter, conclusion, and bibliography. Teaching material developed is used as a means of support and reference for students as well as facilitate teachers in carrying out learning activities.

Based on the results of expert assessments of LKPD, out of 10 indicators assessed there are 7 indicators that are declared highly valid and 3 indicators are declared valid, with minor revisions in the form of advice from experts/practitioners. The developed LKPD is adjusted to the Problem Solving model which consists of 6 phases, namely formulating the problem, analyzing the problem, formulating a hypothesis, 
collecting data, testing the hypothesis, and recommending problem solving. By doing LKPD students are expected to be able to carry out investigative activities or analyze a problem so as to improve their critical thinking skills in solving a problem. Kurniawati and Atmojo [9] explained that students 'worksheets resulting from the development were effective to foster students' critical thinking skills.

Based on the results of the expert's assessment of the Critical Thinking Assessment Sheet showing that of the 4 indicators assessed there were 2 indicators that were declared highly valid and 2 indicators that were declared valid, with minor revisions in the form of advice from experts / practitioners. Critical thinking assessment sheet developed according to 12 indicators of critical thinking according to Ennis [20] namely: focusing questions, analyzing questions, asking and answering questions about an explanation, considering whether the source can be trusted or not, observing and considering a report the results of observation, deduce and consider the results of deduction, induce and consider the results of induction, make and determine the value of consideration, define terms, identify assumptions, determine actions, interact with others.

Based on the results of the expert assessment of the Science Process Skills Assessment Sheet showed that of the 4 indicators assessed there were 3 indicators that were declared highly valid and 1 indicator declared valid, with minor revisions. Science process skills assessment uses science process skills instruments consisting of 7 aspects: formulating the problem, formulating hypotheses, collecting data, conducting experiments, analyzing data, drawing conclusions, and communicating. Based on the results of the expert's assessment of the Teacher Activity Assessment Sheet showed that of the 4 indicators assessed there were 3 indicators that were declared highly valid and 1 indicator declared valid, with a small revision in the form of advice from experts / practitioners. In general, teacher activity assessment sheets are very valid because they can measure what they want to measure, and are relevant to the objectives to be achieved. Based on the results of the expert assessment of the Student Activity Evaluation Sheet and the Student Attitude Assessment Sheet show that all indicators assessed are highly valid, with minor revisions in the form of suggestions. Student Activity Evaluation Sheet and Student Attitude Assessment Sheet are declared to be very valid because it is in accordance with what will be measured and made based on an analysis of students' needs in participating in learning activities.

Based on the results of the expert assessment of the Student Skills Assessment Sheet showed that of the 4 indicators assessed there were 3 indicators that were declared very valid and 1 indicator declared valid, with a small revision in the form of suggestions. The skills of students who are developed emphasize on several aspects of skills when students conduct experiments. The process carried out by researchers to achieve the validity of the device in the process of developing devices based on the analysis of the material, the needs of students, the current curriculum and future targets to be achieved in educational goals. Some of the variables above are indicators that are used as references and are carried out by researchers to develop learning tools so that results are obtained in the form of a valid learning tool according to expert standards (experts and practitioners). Therefore, learning tools developed to be feasible and able to achieve research objectives is to improve students' critical thinking skills in science process skills.

\section{Practicality of Learning Devices}

The practicality of the developed learning device refers to the implementation of the learning process in class in accordance with the research design developed in the learning device. Practicality is measured from the impact caused by the benchmarks in the form of implementation of learning in the form of teacher activities and student activities that are assessed by the observer. Learning activities that have been designed through the process of developing learning tools are assessed for their implementation and their effect on students. The focus of the assessment of the practicality of learning tools is centered on the results of the final stages of development research, namely large group tests or field tests. The use of learning tools with problem solving models to improve critical thinking skills and science process skills of students need accuracy, patience and repeated treatment. This is because students are not accustomed to always thinking critically in solving a problem because they are still accustomed to memorizing concepts only.

In the small group test the teacher's activities at the preliminary, core, and closing stages are categorized as good. During the four meetings, the core activity of the teacher always increases, because the teacher is getting used to doing learning activities using the problem solving model. While in the preliminary and closing activities the teacher does not experience difficulties because it is not too different from the usual learning activities. Likewise also with the activities of students who always experience an increase in each meeting. For the activities of students in the preliminary and closing stages are categorized as good. Whereas at the core stage it is categorized quite well, this is possible because students still have to adapt to the learning model used during the learning process. In general, the activities of students are categorized as good; this shows that the implementation of the lesson plan is good and practical.

In the field test the teacher's activity test at the preliminary, core, and closing stages during the four meetings was considered very well. In the preliminary stage, the core and closing activities of the teacher 
always increase in each meeting. This shows the teacher is able to carry out learning activities using learning tools that have been developed very well, so it can be said that the learning tools developed by researchers are practical.

Students' activities in the field test have increased in each meeting. This shows that there is an interest of students in the ongoing learning activities, there is also a good interaction between the teacher and students so that the learning process can run well in accordance with the learning design that is made. Nur [21] states that the learning process can be made very meaningful by providing opportunities for students to find problems and implement the learning themselves through a learning plan.

According to Nieveen [22] practical is a tool or material that can be used and is easy for teachers and students to use it. This means the teacher is able to manage the class well because all learning devices have been learned and understood by the teacher before testing the device. The results of this study are supported by research that has been reported previously that learning using problem solving models can be one way of providing good teaching experiences [23].

The practicality of learning tools can also be seen from students' self-assessment of the learning process. In the small group test and the field test, the percentage of students' self-assessment was higher in positive responses than in negative responses. This shows that students provide a positive assessment of learning activities using problem solving models, so that the learning tools used can be said to be practical. Mulyasa [24] explained that self-assessment is done by determining the extent to which the abilities that a person has from a learning activity within a certain time span. Self-assessment is used to measure the achievement of students' competencies, foster values of honesty, and enhance the ability to reflect on learning activities.

The practicality of learning tools for students 'responses in the small group test has a positive response above $67 \%$, while in the field test the students' positive response test is above $88 \%$. In general, students' responses to learning using the problem solving model have a high positive response. This shows that learning with problem solving models can be accepted and liked by students. This is in line with research by Irwanto, et al. [25] that students provide a positive response to the implementation of learning activities because the average student feels happy and motivated through the problem solving learning model. Susilowati and Anam [26] reported that learning tools with problem solving models received positive responses from students. Caliskan, et al. [27] states that the application of the device has succeeded in getting a positive response from students towards the learning process.

The learning tools of the research results have been said to be practical, this is supported by research data based on: 1) the implementation of the lesson plans by partner teachers; and 2) students' responses. Plomp and Nieveen [5] state that the practicality of the device can be known from the results of observations of the implementation of learning and students' responses to the learning device.

The results of research on students' responses to learning are in accordance with previous research. Schaal et al. [28] say students feel more competent than students in other courses for implementing a similar approach in the pursuit of the future. Furthermore Seyhan [13] reports that learning devices with problem solving models get positive responses from students. Furthermore Aurah [29] states that students provide a positive response to the problem solving learning model because students perceive that learning with a problem solving model is very beneficial for them to improve their learning achievement.

\section{Effectiveness of Learning Tools}

The effectiveness of learning tools can be seen from the achievement of learning objectives which include learning outcomes, critical thinking, science process skills, attitudes and skills of students. The learning device developed will be categorized as effective if the device is able to achieve research objectives or has more value than the pre-existing learning tools. Student learning outcomes in the small group test as a whole based on the specified KKM value limit of 70 . While the learning outcomes of students in the field test as a whole. Completeness of students' learning outcomes because students are able to solve the questions correctly at each meeting in accordance with predetermined learning indicators.

RPP tools are effective because cognitive learning outcomes have exceeded the established KKM scores. This is due to the items developed that have been declared valid. According to Akbar [30] good test questions are valid, that is, questions that can measure abilities as they are or the results of the tests are in accordance with reality. Appraisal tools are said to be valid if the tool is able to assess what should be assessed, that is, the objectives measured must be in accordance with the material being assessed and the questions in the appraisal measure aspects as described in basic competencies or indicators [31].

Students' critical thinking skills can be seen from the results of multiple choice questions made based on 12 indicators of critical thinking according to Ennis which are divided into 5 aspects, with answer choices given a confidence level of answers on a scale of 0-6. If the choice of confidence answers from a scale 
of 0-2 then the level of confidence of the answer is low, whereas if the choice of confidence answers from a scale of 3-6 then the level of confidence of the answer is high. Categories of critical thinking skills are critical and uncritical. If the answer is correct but the level of confidence of the answer is low, then it is included in the uncritical category. Whereas if the answer is correct and the level of confidence of the answer is high, it is categorized as critical. For answers wrong with a low or high level of confidence, then categorized as not critical.

In the small group test students' critical thinking skills. Overall critical thinking skills of students have increased after participating in learning activities using problem solving models. The N-Gain value obtained from the pre-test and post-test scores is included in the medium category. Likewise the students' critical thinking skills in the field test as a whole have increased, with the $\mathrm{N}$-Gain score included in the medium category. This category shows that students already have a good understanding and mastery of concepts and critical thinking skills after using the learning tools that have been developed. Critical thinking ability is very good, previous reports support the results of this study including learning with problem solving models positively correlated with students' critical thinking skills [32].

Critical thinking skills are very necessary and should be owned by students [33]. The ability to think critically is one of the effectiveness of learning tools [34]. Students' critical thinking skills include formulating problems, formulating hypotheses, collecting data, analyzing data, and making conclusions on average of good categories [35]. Learning with problem solving models has a significant positive impact on students' critical thinking skills [36].

The science process skills of students in the small group test as a whole have increased, with $\mathrm{N}$-gain values included in the medium category. Likewise in the field test the overall science process skills of students have increased, with the value of $\mathrm{N}$-gain included in the medium category. This finding is supported by previous research that shows the implementation of learning tools that are developed effectively used to train science process skills and the strengthening of science learning concepts [29]. Development of learning tools with problem solving models can show an increase in students' competencies, because the existing syntax can accommodate spiritual, social, knowledge and skills competencies [37].

\section{CONCLUSION}

Based on the research results of the development of learning devices, several conclusions are obtained, including:

- Learning tools are said to be valid based on expert opinion including, syllabus, material analysis, teaching material, LKPD, LP critical thinking skills of students, LP science process skills of students, LP teacher activities, LP activities of students, LP attitudes of students, and LP skills of students.

- Learning tools are said to be practical based on the activities of teachers and students who are very good from the implementation of the lesson plan, self-assessment and responses of students categorized as good.

- Learning tools are said to be effective based on learning outcomes that have reached and exceeded the specified KKM, critical thinking skills and increasing scientific process skills, attitudes and skills of students are categorized well.

\section{REFFERENCE}

1. Susilo, H. (2009). Upaya Membelajarkan Guru IPA/Biologi Masa Depan yang Cerdas dan Profesional. Universitas Negeri Malang.

2. Purwandari, N. M. Y., Arcana, I. N., \& Riastini, P. N. (2013). Pengaruh Pendekatan PAIKEM

Terhadap Hasil Belajar IPA Siswa Kelas V SD Negeri 2 Lelateng. MIMBAR PGSD

Undiksha, 1(1).

3. Ningsih, W., \& Widian, N. (2013). Pengembangan Perangkat Pembelajaran IPA Terpadu Tipe Webbed Tema Tercemarkah Airku di Kelas VII SMP. PENDIDIKAN SAINS, 1(01).

4. Setiadi, D. (2014). Model Pembelajaran Berbasis Peningkatan Literasi Sains dan Implementasinya dalam Kurikulum Sains SMP 2013. Jurnal Pijar Mipa, 9(1).

5. Plomp, T., \& Nieveen, N. (2007, November). An introduction to educational design research. In Proceedings of the seminar conducted at the East China Normal University, Shanghai (PR China) (Vol. 23).

6. Desianti, N. W. H., Adnyana, D. P. B., Si, M., \& Setiawan, D. I. G. A. N. (2015). Pengembangan Perangkat Pembelajaran IPA dengan Setting Sains Teknologi Masyarakat untuk Meningkatkan Keterampilan Proses Sains dan Keterampilan Berpikir Kreatif Siswa SMP. Jurnal Pendidikan dan Pembelajaran IPA Indonesia, 5(2).

7. Tawil, M., \& Liliasari, L. (2013). Berpikir Kompleks dan Implementasinya dalam pembelajaran IPA. Makassar: Universitas Negeri Makassar.

8. Filsaime, D. K. (2008). Menguak rahasia berpikir kritis dan kreatif. Jakarta: prestasi pustaka, 21.

9. Gafur, A. (2012). Desain pembelajaran: Konsep, model, dan aplikasinya dalam perencanaan pelaksanaan pembelajaran. Yogyakarta: Ombak.

10. Alebous, T., \& Ayasra, A. H. The Extent to Which the First Three Grades Teachers Use Problem Solving Approach in Teaching Sciences and the Effective Factors in it at Jerash District in Jordan.

11. Huda, M. (2014). Model-Model Pengajaran dan Pembelajaran: Isu-Isu Metodis dan Paradigmatis: Pustaka Pelajar. 
Juli Eka Nugraheni et al; J Adv Educ Philos, March 2020; 4(3): 95-104

12. Greiff, S., Holt, D. V., \& Funke, J. (2013) Perspectives on problem solving in educational assessment: Analytical, interactive, and collaborative problem solving. Journal of Problem Solving, 5(2).

13. Seyhan, H. G. (2014). The Investigation of the Perception of Problem Solving Skills by PreService Science Teachers in the Science Laboratory. International Journal of Physics \& Chemistry Education, 6(2), 142-161.

14. Mukhopadhyay, R. (2013). Problem solving in science learning-some important considerations of a teacher. IOSR Journal of Humanities And Social Science, 8(6), 21-2.

15. Delismar, D., Asyhar, R., \& Hariyadi, B. (2013). Peningkatan kreativitas dan keterampilan proses sains siswa melalui penerapan model Group Investigation. EDUSAINS, 2(1).

16. Hidayat, M.L., Rufaida, A.D., dan Abadi, R. 2013. Ilmu Pengetahuan Alam SMP/MTs Kelas VII Semester 1. Jakarta: Intan Pariwara.

17. Plomp, T., \& Nieveen, N. (2007, November). An introduction to educational design research. In Proceedings of the seminar conducted at the East China Normal University, Shanghai (PR China) (Vol. 23).

18. Permendikbud, S. P. P. D., \& Menengah, B. P. (2016). Cipta Jaya.

19. Atmojo, S. E., \& Kurniawati, W. (2015). Pengembangan Lembar Kerja Berbasis Inkuiri Terintegrasi Kelompok Mata Pelajaran Perekat Bangsa untuk Menumbuhkan Kemampuan Berpikir dan Karakter Ilmiah Siswa. Elementary School (Jurnal Pendidikan dan Pembelajaran Ke-SDan), 2(1).

20. Kartimi, K. (2012). Pengembangan alat ukur berpikir kritis pada konsep senyawa hidrokarbon untuk siswa SMA di Kabupaten Kuningan. Jurnal Pendidikan MIPA Universitas Lampung, 13(1), 121251.

21. Nur, M. (2013). Pendidikan dan Latihan Pembelajaran Inovatif dan Pengembangan Perangkat pembelajaran Bermuatan Keterampilan Berpikir dan Perilaku Berkarakter. Kerjasama Program Studi Magister Pendidikan Biologi PPS Unlam dengan Pusat Sains dan Matematika Sekolah (PSMS) UNESA, 1.

22. Nieveen, N. (1999). Prototyping to reach product quality. In Design approaches and tools in education and training (pp. 125-135). Springer, Dordrecht.

23. Wahyuni, S., Indrawati, I., Sudarti, S., \& Suana, W. (2017). Developing science process skills and problem solving abilities based on outdoor learning in junior high school. Jurnal Pendidikan IPA Indonesia, 6(1).
24. Mulyasa, E. (2013). Pengembangan dan implementasi kurikulum 2013. PT Remaja Rosdakarya.

25. Saputro, A. D., Rohaeti, E., \& Prodjosantoso, A. K. (2018). Promoting Critical Thinking and Problem Solving Skills of Preservice Elementary Teachers through Process-Oriented Guided-Inquiry Learning (POGIL). International Journal of Instruction, 11(4).

26. Susilowati, S. M. E., \& Anam, K. (2017). Improving Students' Scientific Reasoning and Problem-Solving Skills by The 5E Learning Model. Biosaintifika: Journal of Biology \& Biology Education, 9(3), 506-512.

27. Çalışkan, S., Selçuk, G. S., \& Erol, M. (2012). Instruction of problem solving strategies: Effects on physics achievement and self-efficacy beliefs. Journal of Baltic Science Education, 9(1), 20-34.

28. Schaal, S., Matt, M., \& Grübmeyer, S. (2012). Mobile Learning and biodiversity-bridging the gap between outdoor and inquiry learning in preservice science teacher education. Procedia-Social and Behavioral Sciences, 46, 2327-2333.

29. Aurah, C. M. (2013). The Influence of Self-Efficacy Beliefs and Metacognitive Prompting onGenetics Problem Solving Ability among High School Students in Kenya. Ball State University.

30. Akbar, S. D. (2013). Instrumen perangkat pembelajaran.

31. Ratumanan, T. G., \& Laurens, T. (2011). Penilaian hasil belajar pada tingkat satuan pendidikan edisi 2. Yayasan Pengkajian Pengembangan Pendidikan Indonesia Timur dan UNESA, Surabaya.

32. Tambunan, H. (2019). The Effectiveness of the Problem Solving Strategy and the Scientific Approach to Students' Mathematical Capabilities in High Order Thinking Skills. International Electronic Journal of Mathematics Education, 14(2), 293-302.

33. Beaumont, J. (2010). A sequence of critical thinking tasks. Tesol Journal, 1(4), 427-448.

34. Zaini, M., \& Hidayati, N. (2020). Keefektivan Perangkat Rencana Pelaksanaan Pembelajaran melalui Penelitian Berbasis Perancangan. BIOINOVED (Jurnal Biologi-Inovasi Pendidikan), 1(2), 74-82.

35. Muhammad, Z. (2016). Urgensi Penelitian Pengembangan Dalam Menggali Keterampilan Berpikir Kritis.

36. Anderson, J. (2009, October). Mathematics curriculum development and the role of problem solving. In ACSA Conference (Vol. 2009, pp. 1-9).

37. Fadillah, A. (2016). Pengaruh pembelajaran problem solving terhadap kemampuan berpikir kreatif matematis siswa. FIBONACCI: Jurnal Pendidikan Matematika dan Matematika, 2(1), 1-8. 